\title{
CHROMATOGRAPHIC, RHEOLOGICAL AND CYTOCHEMISTRY EVALUATION OF "BACURI" PULP (Platonia insignis MART.)
}

\author{
ANDRÉA CARDOSO DE AQUINO * \\ CÍCERO DE SOUZA LIMA ** \\ FILIPE XAVIER FEITOSA *** \\ MARIA IZABEL GALLÃO **** \\ GUSTAVO ADOLFO SAAVEDRA PINTO ***** \\ HOSIBERTO BATISTA DE SANT'ANA ******
}

\begin{abstract}
"Bacuri" pulp was evaluated for volatile compounds, rheological behavior, and cytochemical analysis. The pulp was also submitted to physicochemical characterization. The effect of temperature on rheological behavior of whole "bacuri" pulp was investigated in this work. The rheological measurements were carried out using a Brookfield Rheometer (Model DV-II +) at shear rate range from 0.25 to $1.50 \mathrm{~s}^{-1}$ at temperatures of $30,40,50,60$ and $70{ }^{\circ} \mathrm{C}$. A total of 36 compounds were detected in the headspace of the "bacuri" pulp - 34 of which were identified. The major compounds were the following: linalool, cis-linalool, trans-linalool oxide, and hotrienol, respectively. The experimental data was adjusted using a power law rheological model, with good agreement. "Bacuri" pulp shows a non-Newtonian behavior, with an apparent viscosity decreasing with increasing temperature. The "bacuri" pulp obtained activation energy at shear rate $1.50 \mathrm{~s}^{-1}$ was $-14.03 \mathrm{~kJ} / \mathrm{mol}$.
\end{abstract}

KEY-WORDS: VISCOSITY; VOLATILE COMPOUNDS; POWER LAW MODEL; Platonia insignis MART.

* Enginner Food, Doctorate in Chemical Engineering, Professor, Department of Food Technology, Universidade Federal do Ceará (UFC), Campus do Pici, Fortaleza, CE, Brazil (e-mail:andreacdeaquino@ gmail.com).

** Chemist, Doctor of Science and Petroleum Engineering, Universidade Federal do Rio Grande do Norte (UFRN), Campus Universitário Lagoa Nova, Natal, RN, Brazil (e-mail: cicerosl@gmail.com).

*** Chemical Engineer, Student Master of Engineering Chemical and Biochemical Processes, UFC, Campus do Pici, Fortaleza, CE, Brazil (e-mail: filipexfeitosa@hotmail.com).

**** Biologist, Ph.D. in Cellular and Structural Biology, Professor, Department of Biology, UFC, Campus do Pici, Fortaleza, CE, Brazil (e-mail: edybel@ufc.br).

***** Chemist, Ph.D. in Technology of Chemical and Biochemical Processes, Research of the Embrapa Tropical Agroindustry, Bioprocess Laboratory, Planalto do Pici, Fortaleza, CE, Brazil (e-mail: gustavo@cnpat. embrapa.br).

****** Chemical Engineer, Ph.D. in Physical Chemistry of Petroleum, Professor, Department of Chemical Engineering, UFC, Campus do Pici, Fortaleza, CE, Brazil (e-mail: hbs@ufc.br). 


\section{INTRODUCTION}

Fruit juice consumption has increased over the last decades in Europe. In 1998, fruit juice consumption was $9.5 \times 10^{9} \mathrm{~L}$ and increased to $11 \times 10^{9} \mathrm{~L}$ in 2007 , meaning an average per capita consumption of $23.7 \mathrm{~L}$. Consumption is expected to grow further by $1.5 \%$ annually, reaching 13.5 $\times 10^{9} \mathrm{~L}$ by 2012. Due to increasing consumer interest in a healthier lifestyle, fruit juice consumption outlooks are forecasted to be favorable. Orange and apple juice remain the most important fruit juices consumed in Europe, representing, in $2007,40.5 \%$ and $18.1 \%$ of the fruit juice market, respectively. Besides a steady growth in the consumption of 'traditional' fruit juices, in recent years there has been an increasing demand for innovative fruit juices with novel and exotic fruit combinations. Introductions of novel beverages with tropical flavors increased between 2003 and 2007. Concrete examples are increased fruit juice introductions containing açaí, acerola and guaraná (SABBE, VERBEKE and DAMME, 2009).

Platonia insignis Mart. belongs to the family Clusiaceae and is commonly known as "bacurizeiro". It is a fruit-bearing and timber tree species originating from the Brazilian Eastern Amazon, more precisely in the state of Pará. It is found in all states of Brazil's North region and in the states of Mato Grosso, Maranhão and Piauí (Van den BERG, 1993).

The fruit of the "bacurizeiro", named "bacuri", is a berry of large and variable size. The edible part, called the pulp, is white, and has a pungent odor and a slightly sweet flavor. It is what makes the "bacuri" one of the fruits that can be marketed both for raw consumption and for the production of refreshments, nectar, jelly, candy sweet paste and others (CLEMENT and VENTURIERI, 1990).

Despite being highly appreciated in the regions where they are grown, "bacuri" pulp may face difficulties in the process of industrialization, due to its high consistency and high adhesion to the seed, making their products very thick and difficult to be marketed within the standards of the Brazilian Legislation (AQUINO, 2008).

Several factors such as temperature (VITALI and RAO, 1984), concentration of total soluble solids (RAO, 1977; HERNANDEZ et al., 1995) and particle size (TANGLERTPAIBUL and RAO, 1987; AHMED, SHIVHARE and RAGHAVAN, 2000) affect the rheological behavior of the fruit's pulp. Namely its creaminess, succulence, softness, suavity and hardness.

According to Ibarz and Barbosa-Cánovas (1999), the importance of understanding the rheological behavior of fruit by-products is in its usage for measuring quality, aside from being indispensable for projects and for the evaluation and operation of food processor equipment. It is also vital in saving energy, which nowadays has become extremely important as operations involving the exchange of heat and mass transfer.

For non-Newtonian fluids, the term viscosity is replaced by apparent viscosity and is a function of the velocity gradient (VIDAL, 2000):

where:

$$
\eta_{\mathrm{ap}}=\mathrm{T} / \mathrm{Y}
$$

$\eta_{\mathrm{ap}}=$ the apparent viscosity (PA.s), $\mathrm{T}=$ the shear stress $(\mathrm{Pa}), \mathrm{Y}=$ the shear rate $\left(\mathrm{s}^{-1}\right)$.

Among the group of pseudoplastic fluids, one finds that most of them exhibit non-Newtonian behavior. These are fluids that are independent of time, without residual stress, which start to drain away under the action of infinitesimal shear stress (VIDAL, 2000). Many food-based fluids exhibit pseudoplastic behavior and are characterized by the Ostwald-De-Waele model (Power law model) (STEFFE, 1996):

$$
\mathrm{T}=\mathrm{KY} \text { or } \quad \log _{10} \mathrm{~T}=\log _{10} \mathrm{~K}+\mathrm{nlog} \log _{10} \mathrm{Y}
$$

where:

$\mathrm{K}=$ the consistency coefficient (Pa.s), $n=$ the flow behavior index (dimensionless), $\mathrm{Y}=$ the shear rate $\left(\mathrm{s}^{-1}\right) ; \mathrm{T}=$ the shear stress $(\mathrm{Pa})$. 
When dividing equation 2 by the shear rate $\left(\log _{10} \mathrm{Y}\right)$, the result is an equation that governs the apparent viscosity of pseudoplastic fluids (eq. 3):

$$
\eta_{\mathrm{ap}}=\mathrm{K} / \mathrm{Y}+\mathrm{n}
$$

In this case, the apparent viscosity of the fluid decreases as the shear stress increases. If, in equation 2, the rheological (flow) behavior index $\mathrm{n}$ is $<1$, the fluid is considered pseudoplastic.

The volatiles are responsible for the characteristic aroma of food, as well as of fruit pulps and their nectars. The composition of volatile compounds in food is very complex because it consists of a large number of organic substances, in addition to which they are also present in very small concentrations ( $\mathrm{mg} / \mathrm{L}$ or $\mu \mathrm{g} / \mathrm{L}$ ). The volatile compounds that contribute to the flavor of the fruit can vary according to the ripening stage, cultivation and climatic conditions, among other things (WILLER, YUSSEFI-MENZLER and SORENSEN, 2008).

The dynamic headspace technique, Aroma Extraction Dilution Analysis (AEDA) was used for extraction of volatile compounds of "bacuri", showing that linalool and methyl hexanoate are primarily responsible for the aroma of the fruit (FRANCO, 2003).

The aim of this work was to investigate the volatile composition, rheological behavior, and cytochemical analysis of the "bacuri" pulp.

\section{MATERIAL AND METHODS}

\subsection{SAMPLE PREPARATION}

"Bacuri" fruit was kindly provided by the Empresa Brasileira de Pesquisa Agropecuária Meio-Norte (Embrapa - Brazilian Agricultural Research Corporation), located in Teresina in the state of Piauí. The depulping process was carried out using an ITAMETAL model 0.25 df bonina depulper, with a stainless steel sieve containing 0.058 inch diameter holes. The pulp obtained was wrapped in polyethylene bags that were sealed in a SULPACK SP-350 machine, and finally frozen in a freezer at a temperature of $-20^{\circ} \mathrm{C}$.

\subsection{RAW MATERIAL CHARACTERIZATION}

"Bacuri" fruit pulp was characterized according to the following methods: moisture and ash (AOAC, 1975); ether extract and acidity (IAL, 1985); protein (AOAC, 1975); AIR (alcohol-insoluble residue), starch (CARVALHO, JOMG and BELLÓ, 2002); pectin, hemicelluloses, cellulose and lignin (SHIEBER et al., 2005); total soluble solids ( $\left.{ }^{\circ} \mathrm{Brix}\right)$ and pH (AOAC, 1992); water activity (Aw) Decagon AquaLab CX-2 meter (DECAGON, 1997); and vitamin C (STROHECKER and HENNING, 1967).

\subsection{VOLATILE COMPOUNDS ANALYSIS}

Volatile compounds were isolated by using solidphase microextraction (SPME) method. The volatiles were sampled by manual headspace solid phase microextraction at $40{ }^{\circ} \mathrm{C}$. The fibre (50 / $30 \mu \mathrm{m}$ DVB/CAR/PDMS, Supelco Co., Bellefonte, P.A.) was pierced into the injection port of the GC/MS after $15 \mathrm{~min}$ of sampling, and then desorbed at $200^{\circ} \mathrm{C}$ for $3 \mathrm{~min}$. A GC equipped with an Shimadzu QP2010 mass-selective detector was used, with the injector and detector maintained at 220 and $250^{\circ} \mathrm{C}$, respectively. The column CP-Sil 8 CB (DB-5) dimensions were $0.25 \mathrm{~mm}$ i.d. $\times 30 \mathrm{~m}$ $\times 0.25 \mu \mathrm{m}$ film thickness.

The carrier gas $(\mathrm{He})$ had a flow rate of $1.0 \mathrm{~mL} / \mathrm{min}$. The temperature program was 
isothermal at $30{ }^{\circ} \mathrm{C}$ for $10 \mathrm{~min}$, increase to $200{ }^{\circ} \mathrm{C}$ at $20^{\circ} \mathrm{C} / \mathrm{min}$, and then held for $10 \mathrm{~min}$. The mass spectrometer was operated in the electron impact (EI) mode with electron energy of $70 \mathrm{eV}$. Compounds were identified by matching mass spectra and retention indices with the NIST Library (NIST, 2005).

\subsection{RHEOLOGICAL MEASUREMENTS}

The rheological behavior was measured in a Brookfield rheometer (Model DV-II +) of concentric cylinders with a small sample adaptor $(13 \mathrm{~mL})$ and SC4-29 spindle. The Thermosel Brookfield accessory was attached to the rheometer to adjust the sample temperature at a range of $30^{\circ} \mathrm{C}$ to $70^{\circ} \mathrm{C}$. The sample was not reused between the temperatures due to the change in rheological properties. For each test, the samples were held for 15 minutes in order to reach the desired temperature.

The shear rate range used $\left(0.25 ; 0.50 ; 0.75 ; 1.00 ; 1.25\right.$ e $\left.1.50 \mathrm{~s}^{-1}\right)$ was determined by performing preliminary tests in which the range that did not show any incorrect readings in all of the measurements was selected.

Experimental data was obtained using WINGATHER32 software, version 2.5 (BROOKFIELD, 2010) where measurements were made in triplicate every 60 seconds, resulting in a total of 75 points. This data was submitted for adjustment by the power law rheological model, using Software Origin 6.0. Statistical parameters Chi-Square $\left(X^{2}\right)$ and regression coefficient $\left(R^{2}\right)$ were determined. It was also measured the following parameters: flow behavior index (n), flow consistency index (k), and the standard deviation (SSR). The values of $n$ and $k$ were submitted to variance analysis (ANOVA) and the Tukey HSD (Honestly Significant Difference) test, up to a $5 \%$ level of probability using the Statistica program (STATSOFT, 2004).

Aside from determining apparent viscosity, the effect of temperature on the apparent viscosity of the "bacuri" pulp, with a constant shear rate $\left(1.50 \mathrm{~s}^{-1}\right)$, was described by the Arrhenius Equation.

\subsection{CYTOCHEMISTRY ANALYSIS}

The pulp was fixed in a solution of $4 \%$ paraformaldehyde and $1 \%$ glutaraldehyde in a sodium phosphate buffer of $0.02 \mathrm{M}$ at pH 7.2 (KARNOVSKY, 1965) for 24 hours at room temperature. After being fixed, the material was dehydrated in a graded series of ethanol concentrations and then soaked in Historesin (Historesin Embedding Kit - Jung). Incisions of 3-4 $\mu \mathrm{m}$ were made using an automatic microtome Leica RM 2065. These samples were submitted to cytochemical coloring of toluidine blue (AT) $0.025 \%$ at pH 4.0 as a metachromatic pigment to detect anionic radicals (VIDAL, 1977). Incisions were examined under a NIKON photomicroscope.

\section{RESULTS AND DISCUSSION}

Table 1 shows the chemical composition of "bacuri" pulp. The moisture content found in this study was $78.79 \mathrm{~g} / 100 \mathrm{~g}^{-1}$, almost identical to the value of $78.4 \mathrm{~g} / 100 \mathrm{~g}^{-1}$ reported by Santos (1988), who has also analyzed "bacuri" fruits originating from the Mid-North Region.

The average levels of protein and ash found in "bacuri" pulp were 1.31 and $0.38 \mathrm{~g} / 100 \mathrm{~g}^{-1}$ respectively (Table 1). These results were lower than those found in the literature (SANTOS, 1988).

The ether extract given was of $1.46 \mathrm{~g} / 100 \mathrm{~g}^{-1}$ of pulp (Table 1), which is lower than the values reported by Santos (1988) and Lima (2007), with values of 1.9 and $2.9 \mathrm{~g} / 100 \mathrm{~g}^{-1}$, respectively.

The average value of $19.87^{\circ} \mathrm{Brix}$ of Total Soluble Solids (TSS) found was very close to those reported by Santos (1988) and Guimarães, Mota e Nazaré (1992), who obtained 19.10; and $18.73{ }^{\circ}$ Brix, respectively. However, Villachica et al. (1996), Souza et al. (2001) and Aguiar (2006) obtained lower values of $16.40,14.1$ and $12.2^{\circ}$ Brix, respectively. 
The total sugar content was $10.56 \mathrm{~g} / 100 \mathrm{~g}^{-1}$ (Table 1), approaching the value of $10.98 \mathrm{~g} / 100 \mathrm{~g}^{-1}$ found by Santos (1988). Aguiar (2006) reported a lower value of $8.6 \mathrm{~g} / 100 \mathrm{~g}^{-1}$. For reducing sugars, a value of $5.89 \mathrm{~g} / 100 \mathrm{~g}^{-1}$ was found, corresponding to the content of the literature.

The Total Titratable Acidity (TTA) was $1.34 \mathrm{~g} / 100 \mathrm{~g}^{-1}$, lying close to the values quoted by Santos (1988), Villachica et al. (1996), Aguiar (2006) and Souza et al. (2001), whose average values were $1.2 ; 1.6 ; 1.5$ and $1.37 \mathrm{~g} / 100 \mathrm{~g}^{-1}$, respectively. Thus, the TSS/TTA parameter was calculated as 14.81 .

The vitamin $\mathrm{C}$ content was found to be $3.88 \mathrm{mg} / 100 \mathrm{~g}^{-1}$. This value is lower than the value reported by Calzavara (1970) of $33 \mathrm{mg} / 100 \mathrm{~g} \mathrm{~g}^{-1}$, by Santos (1988) of $10 \mathrm{mg} / 100 \mathrm{~g}^{-1}$ and by Aguiar (2006) of $6 \mathrm{mg} / 100 \mathrm{~g} \mathrm{~g}^{-1}$. Nazaré (2000) found only traces of vitamin C. But the total phenolic content was found to be $0.51 \mathrm{~g} / 100 \mathrm{~g}^{-1}$, being greater than the value of $0.24 \mathrm{~g} / 100 \mathrm{~g}^{-1}$ reported by Aguiar (2006).

The content of Alcohol Insoluble Residues (AIR) was quantified at $7.59 \mathrm{~g} / 100 \mathrm{~g} \mathrm{~g}^{-1}$, with $3.33 \mathrm{~g} / 100 \mathrm{~g} \mathrm{~g}^{-1}$ being of pectin. Aguiar (2006) reported a total pectin value of $1.32 \mathrm{~g} / 100 \mathrm{~g}^{-1}$. Villachica et al. (1996), in the book Frutales y hortaliças promissoras de la Amazônia (Promising fruit and vegetables from the Amazon), reported only $0.12 \mathrm{~g} / 100 \mathrm{~g}^{-1}$. The content of hemicellulose and cellulose + lignin was $1.67 \mathrm{~g} / 100 \mathrm{~g}^{-1}$ and $2.59 \mathrm{~g} / 100 \mathrm{~g}^{-1}$, respectively.

The Water Activity (WA) of "bacuri" pulp was 0.983 , which is consistent with the value of 0.985 determined by Bezerra (2004).

The "bacuri" pulp had a pH of 3.56, with an acidic character, like most fruits, due to the presence of organic acids. The $\mathrm{pH}$ values found in the literature by Santos (1988), Moraes et al. (1994), Villachica et al. (1996) and Aguiar (2006) range from 2.8 to 3.5.

TABLE 1 - COMPOSITION OF WHOLE "BACURI" PULP

\section{PARAMETERS}

\section{Moisture $\left(\mathrm{g} .100 \mathrm{~g}^{-1}\right)$}

Fat $\left(\mathrm{g} .100 \mathrm{~g}^{-1}\right)$

Protein $\left(\mathrm{g} .100 \mathrm{~g} \mathrm{~g}^{-1}\right)$

Ash $\left(\mathrm{g} .100 \mathrm{~g}^{-1}\right)$

Total carbohydrate $\left(\mathrm{g} .100 \mathrm{~g}^{-1}\right)$

Total sugars $\left(\mathrm{g} .100 \mathrm{~g}^{-1}\right)$

Reducing sugars $\left(\mathrm{g} .100 \mathrm{~g}^{-1}\right)$

$\operatorname{AIR}^{1}\left(\mathrm{~g} .100 \mathrm{~g}^{-1}\right)$

Pectin $\left(\mathrm{g} .100 \mathrm{~g}^{-1}\right)$

Hemicellulose $\left(\mathrm{g} .100 \mathrm{~g}^{-1}\right)$

Cellulose and lignin $\left(\mathrm{g} .100 \mathrm{~g}^{-1}\right)$

Total Phenol $\left(\mathrm{g} .100 \mathrm{~g} \mathrm{~g}^{-1}\right)$

Acidity $\left(\mathrm{g} .100 \mathrm{~g} \mathrm{~g}^{-1}\right)$

Soluble solids ( $\left.{ }^{\circ} \mathrm{Brix}\right)$

Vitamin C (mg.100 g $\left.\mathrm{g}^{-1}\right)$

$\mathrm{pH}$

Water activity

Platonia insignis MART.

$$
\begin{gathered}
78.79 \pm 1.37 \\
1.46 \pm 0.08 \\
1.31 \pm 0.12 \\
0.38 \pm 0.02 \\
18.24 \pm 0.00 \\
10.56 \pm 0.24 \\
5.89 \pm 0.27 \\
7.59 \pm 0.18 \\
3.33 \pm 0.19 \\
1.67 \pm 0.31 \\
2.59 \pm 0.06 \\
0.51 \pm 0.00 \\
1.34 \pm 0.05 \\
19.87 \pm 0.15 \\
3.88 \pm 0.00 \\
3.56 \pm 0.01 \\
0.983 \pm 0.00
\end{gathered}
$$

\footnotetext{
${ }^{1}$ AIR = Alcohol-insoluble Residue.
}

The quantities of the volatile compounds isolated from "bacuri" pulp are reported in Figure 1 and Table 2. Thirty-six compounds were detected in the headspace of the "bacuri" pulp, 34 of which were identified through GC/MS and retention indices data. The "bacuri" pulp showed relatively higher quantities of linalool, cis-linalool, trans-linalool oxide, and hotrienol. 
Boulanger, Chassagne and Crouzet (1999) reported the presence in higher quantities of oxygenated and hydrocarbon terpenes and, to a lesser degree, aldehydes in "bacuri" pulp during heating. More particularly, linalool, linalool furanoxides, R-terpineol, hotrienol, nerol oxide, nerol, and geraniol were isolated in more important quantities.

Villachica et al. (1996) reports the presence of significant amounts of linalool, a substance responsible for the flavor and aroma of "bacuri", and also the presence of 2-heptanone and cis-3hexenyl acetate, which promotes an additional effect on the aroma of the pulp "bacuri".

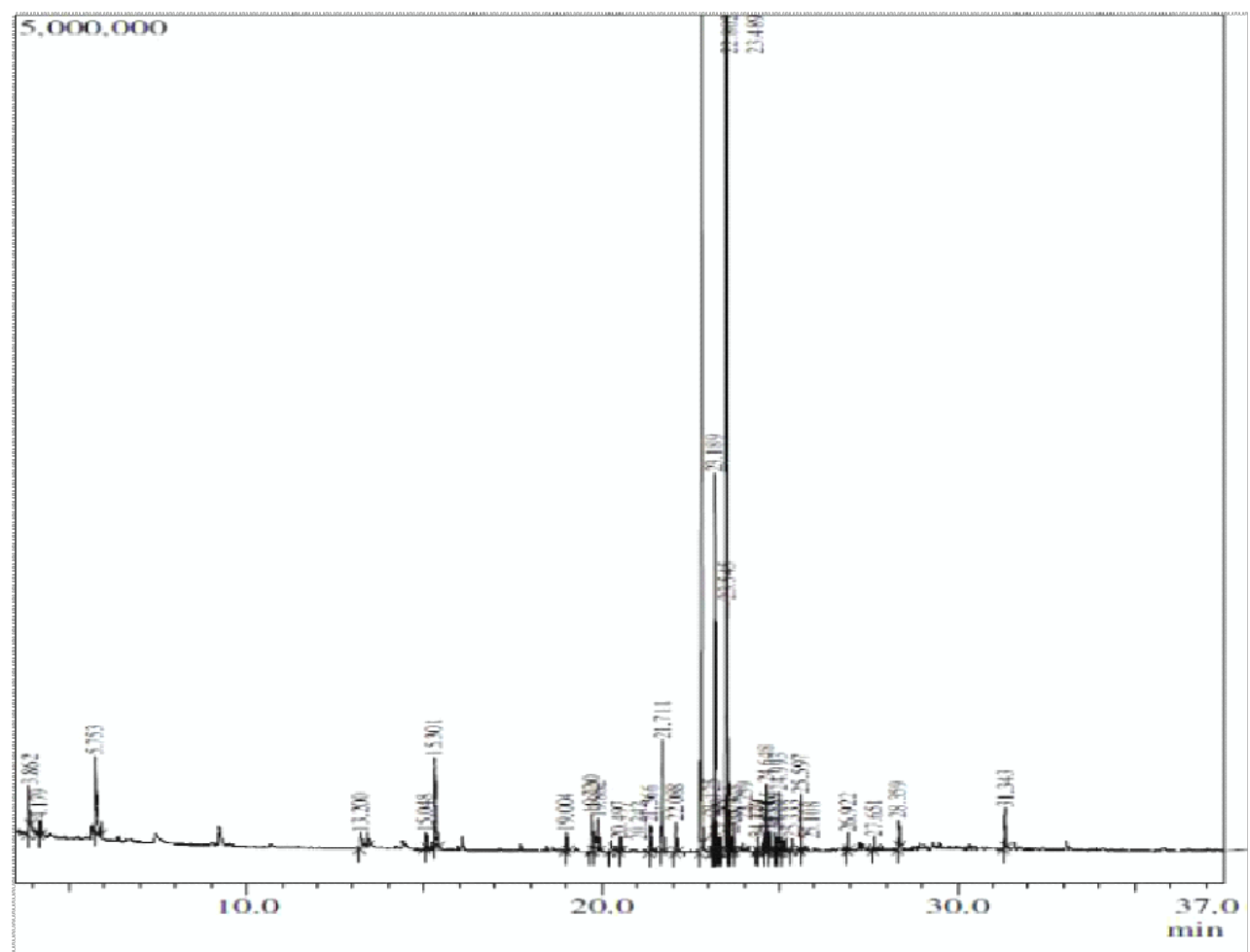

FIGURE 1 - THE GC-MS TOTAL ION PEAKS MAP OF VOLATILE COMPONENTS IN "BACURI" PULP

Alves and Jennings (1979) identified by simultaneous distillation-extraction (SDE) 12 volatile compounds with a predominance of linalool and its cis and trans oxides. Among the 12 compounds found, and linalool showed high levels heptones 2-and 3-hexenyl acetate showed low concentrations. However, these were considered responsible for the flavor of "bacuri".

Rheological parameters obtained by adjusting the power law model for the "bacuri" pulp in the temperature range are shown in Table 3.

The model described properly the rheological behavior of the "bacuri" pulp throughout the entire temperature range studied, where the determination coefficient $\left(R^{2}\right)$ for all formulations was superior to 0.97 , independent of the temperature and chi-square values $\left(X^{2}\right)$ approaching zero. This indicates that the values predicted by the model are close to those of the tested values, because the $X^{2}$ value reveals in what measure the values obtained are different from those expected.

The flow behavior index $(n)$ showed lower values than the unit, indicating pseudoplastic behavior for all studied temperatures. A significant difference was found $(P<0.05)$ between the variables of the flow consistency index $(k)$ and the flow behavior index $(n)$, measured separately, where one could observe a tendency for reduced consistency and increased pseudoplasticity of the fluid as temperature increased. Similar behaviors were observed in research done by Haminiuk et al. (2006) on the whole pulp of "araçá" (Psidium cattleianum), Grangeiro et al. (2007) study of the rheological behavior of the cactus pear concentrated pulps, and in Vidal et al. (2006) study of the rheology of squeezed mango pulp. 
TABLE 2 - VOLATILE COMPOUNDS OF THE “BACURI” PULP

\begin{tabular}{|c|c|c|c|c|c|}
\hline NO. & TR & IR & *IR & $\begin{array}{l}\text { RELATIVE } \\
\text { AREA (\%) }\end{array}$ & COMPOUNDS \\
\hline 1 & 3.862 & $<800$ & $683-686$ & 0.52 & 1-penten-3-ol \\
\hline 2 & 4.179 & $<800$ & 700 & 0.18 & heptane \\
\hline 3 & 5.753 & $<800$ & $730-747$ & 1.43 & 2-methyl-1-butanol \\
\hline 4 & 13.200 & 861 & $853-857$ & 0.53 & trans-2-hexenal \\
\hline 5 & 15.048 & 888 & $886-898$ & 0.26 & stirene \\
\hline 6 & 15.301 & 892 & $888-898$ & 1.65 & 2-heptanone \\
\hline 7 & 19.004 & 970 & 972 & 0.31 & 2.2.6-trimethyl-6-viniltetrahidropiran \\
\hline 8 & 19.720 & 985 & 984 & 0.64 & (metoximethyl)-benzene \\
\hline 9 & 19.882 & 989 & $987-989$ & 0.82 & $\beta$-mircene \\
\hline 10 & 20.242 & 997 & - & 0.23 & ND \\
\hline 11 & 20.497 & 1004 & 1000 & 0.18 & octanal \\
\hline 12 & 21.366 & 1032 & 1017 & 0.54 & limonene \\
\hline 13 & 21.711 & 1043 & 1035 & 1.68 & cis- $\beta$-ocimene \\
\hline 14 & 22.088 & 1055 & 1048 & 0.45 & trans- $\beta$-ocimene \\
\hline 15 & 22.802 & 1078 & 1068 & 15.44 & cis-linalool \\
\hline 16 & 23.125 & 1088 & 1086 & 0.35 & terpinolene \\
\hline 17 & 23.189 & 1090 & 1088 & 4.05 & trans-linalool oxide \\
\hline 18 & 23.239 & 1092 & 1090 & 0.25 & p-cymene \\
\hline 19 & 23.299 & 1093 & 1091-1096 & 0.13 & 2-nonanone \\
\hline 20 & 23.489 & 1100 & $1094-1103$ & 63.46 & linalool \\
\hline 21 & 23.545 & 1103 & 1101 & 3.06 & hotrienol \\
\hline 22 & 23.674 & 1111 & $1102-1112$ & 0.15 & cis-rose oxide \\
\hline 23 & 23.723 & 1114 & 1117 & 0.25 & 2-methyl-6-methylene-1.7-octadien-3-one \\
\hline 24 & 24.370 & 1156 & 1153 & 0.11 & neril oxide \\
\hline 25 & 24.541 & 1167 & - & 0.10 & ND \\
\hline 26 & 24.648 & 1174 & 1157 & 0.57 & cis-epoxy linalool \\
\hline 27 & 24.715 & 1179 & 1164 & 0.18 & trans-epoxy linalool \\
\hline 28 & 24.889 & 1190 & 1186 & 0.23 & (3trans)-2.6-dimethyl-3.7-octadiene-2.6-diol \\
\hline 29 & 24.993 & 1197 & $1180-1195$ & 0.54 & a-terpineol \\
\hline 30 & 25.108 & 1206 & $1202-1206$ & 0.11 & decanal \\
\hline 31 & 25.333 & 1228 & 1228 & 0.10 & $\beta$-citronellol \\
\hline 32 & 25.597 & 1253 & 1256 & 0.44 & geraniol \\
\hline 33 & 26.992 & 1398 & 1400 & 0.14 & tetradecane \\
\hline 34 & 27.651 & 1498 & 1500 & 0.08 & pentadecane \\
\hline 35 & 28.359 & 1591 & - & 0.42 & phthalate* $^{*}$ \\
\hline 36 & 31.343 & 1857 & - & 0.42 & phthalate $^{*}$ \\
\hline
\end{tabular}

$\mathrm{TR}=$ Retention time calculated on the chromatographic conditions used in this work.

IR1 = Retention Index calculated on the chromatographic conditions used in this study.

${ }^{*} \mathrm{IR}=$ Retention Index found in NIST database (2007) and literature.

ND $=$ not detected.

${ }^{*}$ Compound tentatively identified. 


\begin{tabular}{|c|c|c|c|c|}
\hline $\begin{array}{l}\text { Temperature } \\
\left({ }^{\circ} \mathrm{C}\right)\end{array}$ & $\begin{array}{c}\text { Consistency } \\
\text { coefficient K } \\
\left(\mathrm{Pa} \mathrm{s}^{\mathrm{n}}\right)\end{array}$ & $\begin{array}{l}\text { Flow behavior } \\
\text { index } n \\
\text { (dimensionless) }\end{array}$ & $x^{2}$ & SSR \\
\hline
\end{tabular}

\begin{tabular}{llllll}
\hline 30 & $1.38030^{\mathrm{b}}$ & $0.33365^{\mathrm{a}}$ & 0.0001 & 0.0006 & 0.9980 \\
40 & $1.40797^{\mathrm{a}}$ & $0.21298^{\mathrm{d}}$ & 0.0002 & 0.0011 & 0.9927 \\
50 & $1.11061^{\mathrm{c}}$ & $0.25965^{\mathrm{b}}$ & 0.0007 & 0.0029 & 0.9798 \\
60 & $0.8876^{\mathrm{d}}$ & $0.21345^{\mathrm{c}}$ & 0.0000 & 0.0002 & 0.9968 \\
70 & $0.76598^{\mathrm{e}}$ & $0.19216^{\mathrm{e}}$ & 0.0003 & 0.0012 & 0.9701 \\
\hline
\end{tabular}

Data superscripts with the same letters are not statistically different $(P>0.05)$ in each column. SSR - sum of squared residuals.

Figure 2 shows the behavior of the "bacuri" pulp as from the relationship between shear stress versus shear rate in different temperatures.

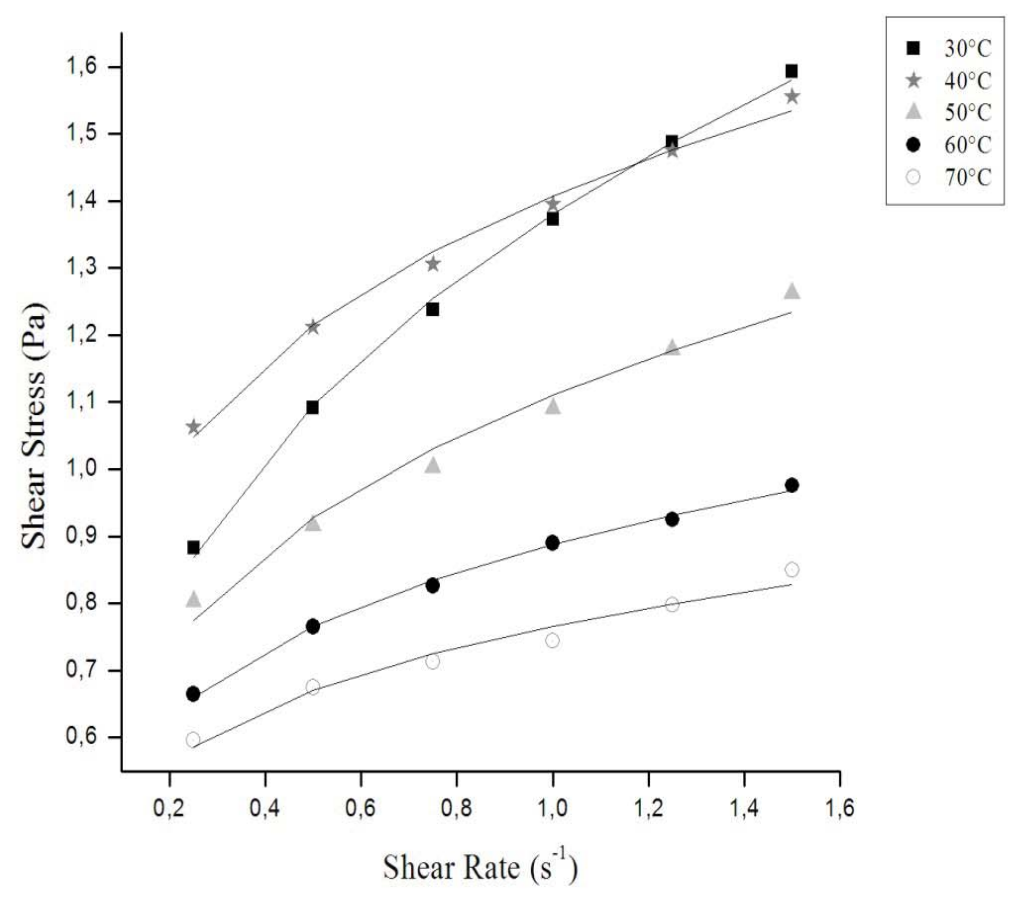

\section{FIGURE 2 - POWER LAW MODEL FITTED TO THE WHOLE "BACURI" \\ PULP AT $30^{\circ} \mathrm{C}(\square), 40^{\circ} \mathrm{C}(\star), 50^{\circ} \mathrm{C}(\Delta), 60^{\circ} \mathrm{C}(\bullet), 70^{\circ} \mathrm{C}(\mathrm{O})$}

Marked dots represent the average value of the experimental data of the rheograms, while the continuous lines are the result of adjustments by the power law fluid model. The aggregation of dots demonstrates non-random behavior, with distribution without dispersion, making the rheological 
model representative for defining the generic behavior from the experimental dots, as quoted before.

The shear stress profile at $40{ }^{\circ} \mathrm{C}$ probably caused an effect on the pulp's soluble pectic fraction, making the sample firmer and more uniform, and consequently exhibiting a higher shear stress profile. From a temperature of $50{ }^{\circ} \mathrm{C}$ and upwards, samples showed a gradual reduction in shear stress as the temperature increased. This decrease in shear stress can probably be explained by the structural collapse of the pulps molecules (ALPARSLAN and HAYTA, 2002; RAO, 1977).

Figure 3 shows apparent viscosity versus shear rate of "bacuri" pulp in the test for different temperatures.

A decrease in apparent viscosity with an increase in shear rate confirms the characteristic of "bacuri" pulp as a pseudoplastic fluid. The greatest reduction in viscosity among the lowest shear rates probably indicates the initially small alignment of the pulp fibers with the flow. In the highest shear rates, fibers would be completely aligned with the flux, and an increase in the flow velocity would not have increased its influence. Decreases in viscosity with temperature increase can also be attributed to an increase in intermolecular distances provoked by heating, which reduces the forces of attraction between molecules, and an increase in the alignment of constituent molecules, therefore elevating its fluidity.

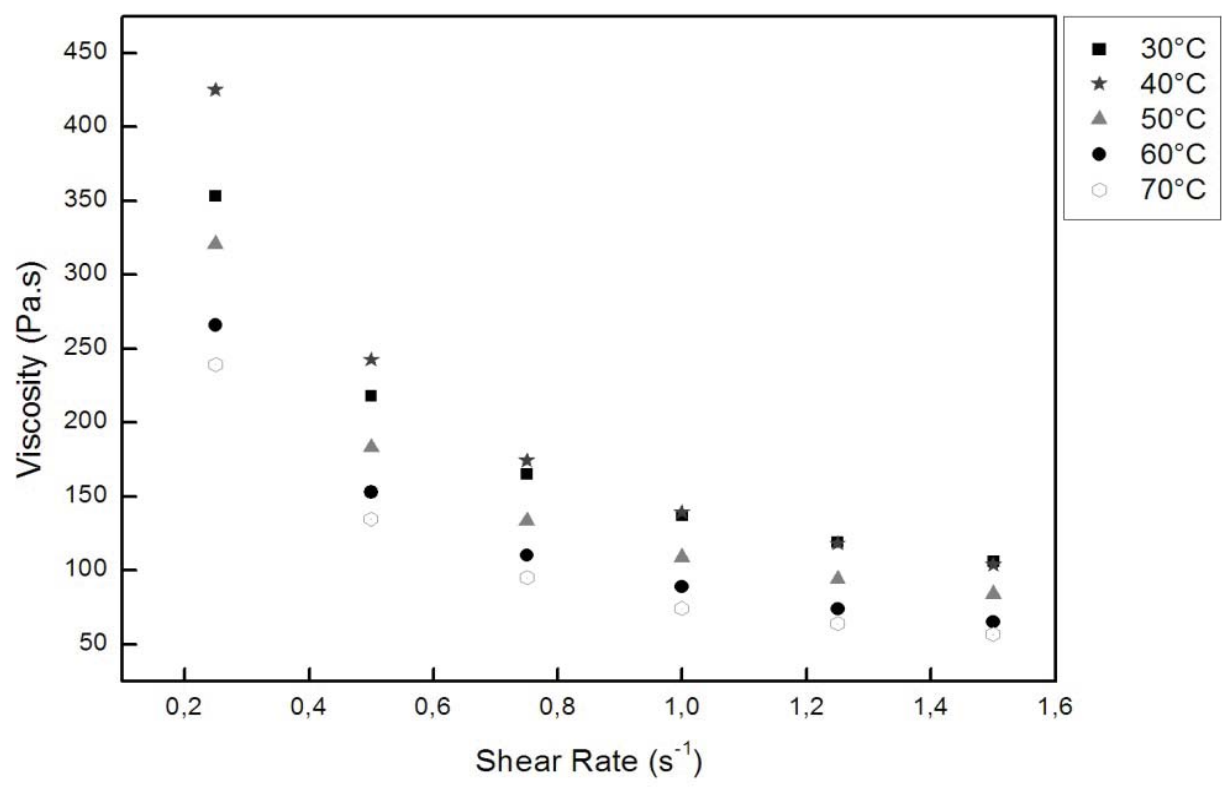

\section{FIGURE 3 - APPARENT VISCOSITY OF THE WHOLE "BACURI" PULP CALCULATED BY THE POWER LAW AT $30^{\circ} \mathrm{C}(\mathbf{\square}), 40^{\circ} \mathrm{C}(\star), 50^{\circ} \mathrm{C}(\mathbf{\Delta}), 60^{\circ} \mathrm{C}(0), 70^{\circ} \mathrm{C}$}

Results shown in Figure 3 are in agreement with the literature as Torres, Queiroz and Figueirêdo (2003) in "umbu-cajá" (Spondias spp.) pulp, Vidal et al. (2006) in mango pulp, and Branco and Gasparetto (2003) in ternary mixtures of mango, orange and carrot, where an increase in temperature provoked a decrease in viscosity.

Figure 4 shows the effect of temperature on the apparent viscosity of the "bacuri" pulp with a constant shear rate described by the Arrhenius Equation.

The Arrhenius model provided a satisfactory description of the effect of temperature on the apparent viscosity of the "bacuri" pulp at a constant shear rate of $1.50 \mathrm{~s}^{-1}$. The activation energy calculated for the "bacuri" pulp was $-14.811 \mathrm{~kJ} / \mathrm{mol}$, with a determination coefficient $\left(R^{2}\right)$ of 0.94 and a standard error of 0.08 .

According to Haminiuk et al. (2005), the higher the number of soluble solids, the lower the value of activation energy $\left(E_{a}\right)$. This explains the low value of activation energy obtained, because 
"bacuri" pulp exhibits a high number of dissolved sugars (19.87 ${ }^{\circ}$ Brix), see Table 1.

According to Nagy, Chen and Shaw (1993), fruit pulp presents a high quantity of insoluble particulate matter. For this reason, it presents a highly non-Newtonian behavior due to the disproportional difference between shear stress and shear rate values.

In general, its rheological behaviour shows that the pulp of "bacuri" is a highly consistent fluid, and therefore it may face difficulties in the industrialization process such as clogging sieves and filters, mixing without uniformity, difficulty in drainage and pumping as well as high energy costs in operations involving the transfer of heat and mass.

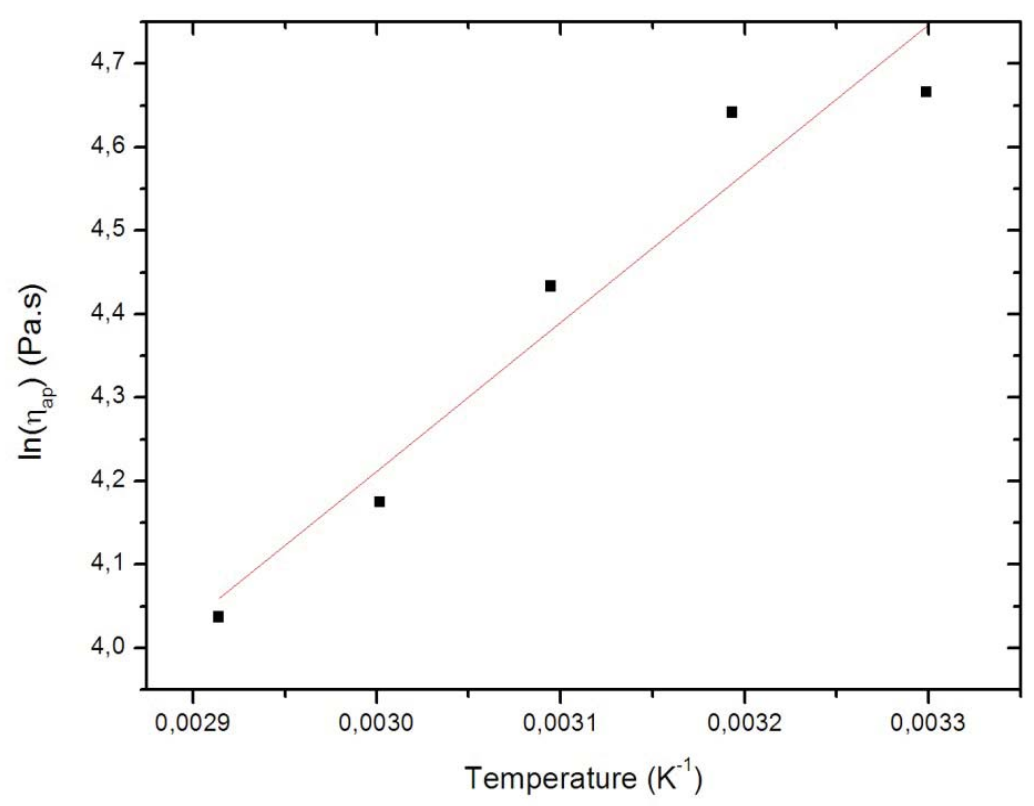

\section{FIGURE 4 - TEMPERATURE EFFECT ON APPARENT VISCOSITY FITTED BY THE POWER LAW MODEL TO THE WHOLE "BACURI" PULP}

Figure 5 shows some of these particles derived from the tissue of the "bacuri" pulp by means of the cytochemical coloring with toluidine blue pigment.
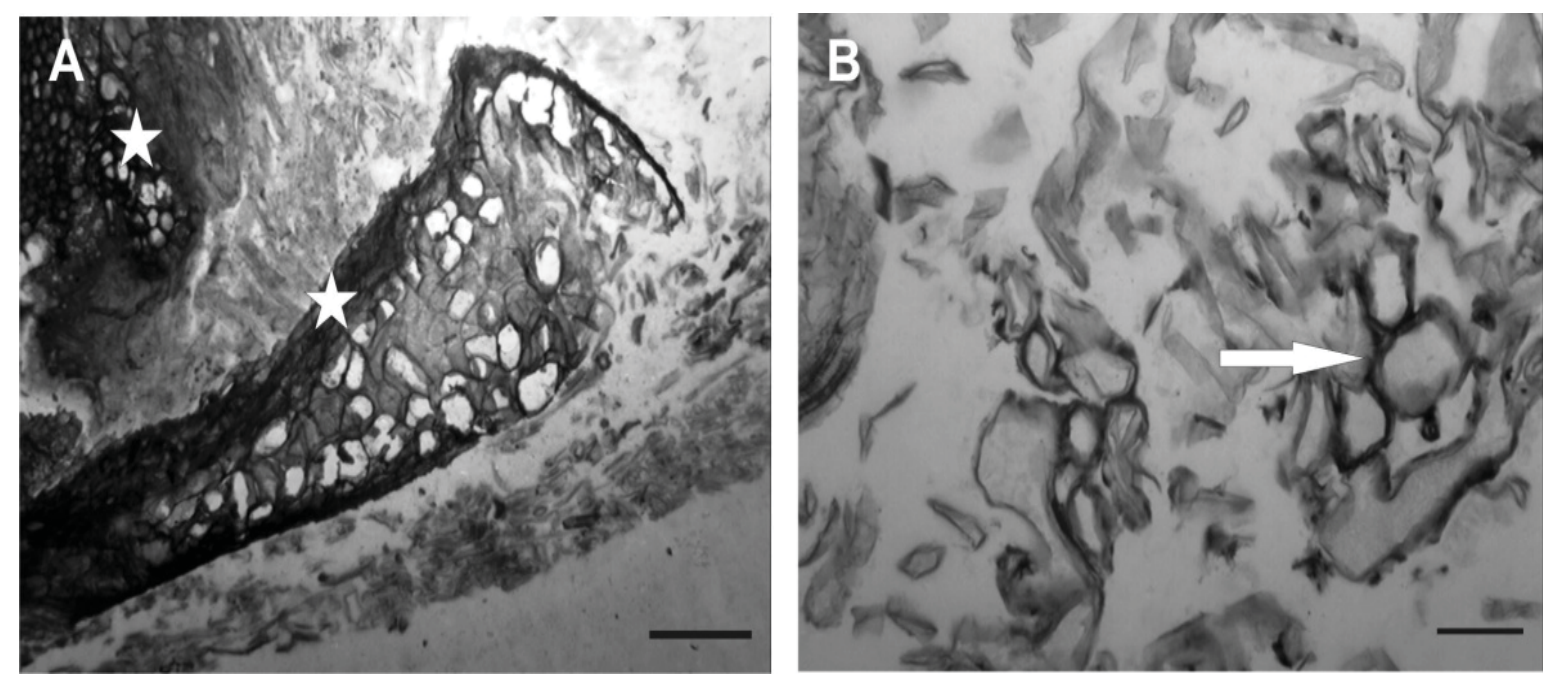

FIGURE 5 - PULP “BACURI” STAINED WITH $0.025 \%$ TOLUIDINE BLUE pH 4.0

A) PRESENCE OF LIGNIFIED MATERIAL ( $\star$ ). BAR: $300 \mu \mathrm{m}$;

B) CELLS OF THE FRUIT $(\rightarrow)$. BAR: $100 \mu \mathrm{m}$ 
Stars shown in Figure 5A indicate the presence of lignified wood vessels. This lignified area may have been responsible for the presence of small seed particles that were dragged along with the pulp during depulping. The presence of pectin in the cell wall and middle lamella can be observed by means of the arrow shown in Figure 5B, where some cells show walls without ruptures while other cells present lack of structure due to the effect of the depulping screen, which caused a disruption in the cell walls of the "bacuri" pulp tissue during depulping (Figure 5B).

Given the results of the physicochemical and cytochemical analyses, which revealed considerable amounts of pectin, hemicellulose, cellulose and lignin in "bacuri" pulp, and knowing that these substances are the main responsible for the high consistency of "bacuri" pulp, it becomes possible to hypothesize that the reduction of pulp consistency can be achieved by enzymatic maceration using commercial enzyme preparations with pectinolytic, hemicellulolytic and cellulolytic activities.

The application of "macerating" enzymes on "bacuri" pulp can reduce its consistency, and thus enable its use as a raw material in the manufacturing of other products such as nectars, placing them within the standards required by the Ministry of Agriculture and Food Supply by Normative Ruling No. 12 of 4 September 2003 (BRASIL, 2003).

\section{CONCLUSION}

A total of 36 compounds were detected in the headspace of the "bacuri" pulp - 34 of which were identified. The major compounds were the following: linalool, cis-linalool, trans-linalool oxide, and hotrienol, respectively.

"Bacuri" pulp has shown non-Newtonian behavior, due to the disproportional difference between shear stress and shear rate values. The fluid exhibited a pseudoplastic characteristic due to the fact that the value of $n$ was lower than the unit.

The rheological power law model better described the pseudoplastic behavior of the "bacuri" pulp, resulting in an adequate adjustment throughout the range of temperatures studied, showing satisfactory values for the determination coefficient $\left(R^{2}\right)$ and chi-square $\left(X^{2}\right)$ values approaching zero.

"Bacuri" pulp showed a higher level of soluble solids, exhibiting negative activation energy of $-14.811 \mathrm{~kJ} / \mathrm{mol}$ and a large quantity of carbohydrates stained with toluidine blue.

According to the results of the chemical, physicochemical and chromatographic analyses, "bacuri" pulp is a proven and considerable source of nutrients, indicating that this pulp could be considered as a raw material of industrial interest for the production of nectar. However, the cytochemical and rheological analyses revealed that the high consistency of "bacuri" pulp could cause problems in the handling, processing and legislation in the industrialization process.

\section{RESUMO}

\section{AVALIAÇÃO CROMATOGRÁFICA, REOLÓGICA E CITOQUÍMICA DE POLPA DE BACURI (Platonia insignis MART.)}

Avaliou-se a polpa de bacuri com o objetivo de adquirir conhecimentos importantes para o avanço tecnológico dessa matéria-prima. Foram avaliados os compostos voláteis, o comportamento reológico e a estrutura citoquímica da polpa de bacuri, efetuando-se também sua caracterização físico-química. Investigou-se o efeito da temperatura sobre o comportamento reológico da polpa de bacuri por meio de medições reológicas efetuadas em Reômetro Brookfield (Modelo DV-II +), utilizando a faixa de taxa de cisalhamento de 0,25 a 1,50 s , nas temperaturas de 30 a $70{ }^{\circ} \mathrm{C}$. Dos 36 compostos voláteis da polpa de bacuri detectados no headspace, 34 foram identificados. Os compostos voláteis encontrados em maior quantidade foram: linalol, cis-linalol, óxido de trans-linalol, e hotrienol, respectivamente. Os dados experimentais da análise reológica foram ajustados por meio do modelo de lei de potência. A polpa de bacuri mostrou comportamento não newtoniano e apresentou o valor de energia de ativação de $-14,03 \mathrm{~kJ} / \mathrm{mol}$ na taxa de cisalhamento fixa de 1,50 s-1. 


\section{REFERENCES}

1 AGUIAR, L.P. Qualidade e potencial de utilização de bacuris oriundos da região Meio-Norte. 2006.122 p. Dissertação (Mestrado em Tecnologia de Alimentos), Universidade Federal do Ceará, Fortaleza, 2006.

2 AQUINO, A.C. Eficiência da maceração enzimática na polpa de bacuri (Platonia insignis Mart.). 2005.115 p. Dissertação (Mestrado em Tecnologia de Alimentos), Universidade Federal do Ceará, Fortaleza, 2008.

3 AHMED, J.; SHIVHARE, U.S.; RAGHAVAN, G.S.V. Rheological characteristics and kinetics of colour degradation of green chili puree. Journal of Food Engineering, v.44, n.4, p.239-244, 2000.

4 ALPARSLAN, M.; HAYTA, M. Rheological and sensory properties of pekmez (grape molasses)/tahin (sesame paste) blends. Journal of Food Engineering, v.54, n.1, p.89-93, 2002.

5 ALVES, S.M.; JENNINGS, W.G. Volatiles composition of certain Amazonian fruits. Food Chemistry, n.4, p.149-159, 1979

6 AOAC. Association of Official Analytical Chemists. Official methods of analysis of the AOAC. 12 ${ }^{\text {th }}$ ed. Washington, 1992.

7 AOAC. Association of Official Analytical Chemists. Official methods of analysis of the AOAC. 11 th ed. Washington, 1975.

8 BEZERRA, G.A.S.; MAIA, G.A.; FIGUEIREDO, R.W.; GOMES, A.M.M.; FILHO, M.S.M.S. Influência da redução da atividade de água, adição de conservantes e branqueamento na preservação da polpa de bacuri por métodos combinados. Boletim do CEPPA, v.22, n.2, p.217-232, 2004.

9 BOULANGER, R.; CHASSAGNE, D.; CROUZET, J. Free and bound flavour components of Amazonian fruits. 1. Bacuri. Flavour Fragrance J., n.14, p.303-311, 1999.

10 BRANCO, I.G.; GASPARETTO, C.A. Aplicação da metodologia de superfície de resposta para o estudo do efeito da temperatura sobre o comportamento reológico de misturas ternárias de polpa de manga e sucos de laranja e cenoura. Ciência e Tecnologia de Alimentos, n.23, p.166-171, 2003.

11 BRASIL. Ministério da Agricultura e do Abastecimento. Secretaria de Defesa Agropecuária. Instrução Normativa n. 12, de 4 de setembro de 2003. Aprova o regulamento de identidade e qualidade geral para suco tropical; os padrões de identidade e qualidade dos sucos tropicais de abacaxi, acerola, cajá, caju, goiaba, graviola, mamão, manga, mangaba, maracujá e pitanga; e os padrões de identidade e qualidade dos néctares de abacaxi, acerola, cajá, caju, goiaba, graviola, mamão, manga, mangaba, maracujá, pêssego e pitanga. Diário Oficial [da] República Federativa do Brasil, Brasília, 9 de setembro de 2003.

12 BROOKFIELD ENGINEERING LABORATORIES. Brookfield DV-II+ pro programmable viscometer operating instructions manual no. M/03-165-C0508W. Available at: www.brookfieldengineering.com.htm Access on: September 23, 2005.

13 CALZAVARA, B.B.G. Fruteiras: abieiro, abricozeiro, bacurizeiro, biribazeiro, cupuacuzeiro. Belém: IPEAN, 1970.

14 CARVALHO, H.H.; JOMG, E.V.; BELLÓ, R.M. Alimentos: métodos físicos e químicos de analyses. Porto Alegre: UFRGS, 2002.

15 CLEMENT, C.R.; VENTURIERI, G.A. bacuri and cupuassu. In: NAGY, S.; SHAW, P.E.; WARDOWISKI, W.G. Fruits of tropical and subtropical origin: composition, properties and uses. Lake Alfred: Florida Department of Citrus, 1990. p.178-192.

16 DECAGON DEVICES INC. AquaLab operator's manual. Revision 2. Pullman, WA, 1997.

17 FRANCO, M.R.B. Aroma e sabor de alimentos. São Paulo: Varela, 2003.

18 GRANGEIRO, A.A.; QUEIROZ, A.J.M.; FIGUEIRÊDO, R.M.F.; MATA, M.E. R.M.C. Viscosidades de polpas concentradas de figo-da-índia. Revista Brasileira Agrociência, v.13, n.2, p.219-224, 2007.

19 GUIMARÃES, A.D.G.; MOTA, M.G.C.; NAZARÉ, R.F.R. de. Coleta de germoplasma de bacuri (Platonia insignis Mart.) na Amazônia. Belém: Embrapa - CPATU, 1992.

20 HAMINIUK, C.W.I.; SIERAKOWSKI, M.R.; VIDAL, J.R.M.B.; MASSON, M.L. Influence of temperature on the rheological behavior of whole araçá pulp (Psidium cattleianum Sabine). LWT- Food Science and Technology, v.39, n.4, p.426-430, 2005. 
21 HAMINIUK, C.W.I.; SIERAKOWSKI, M.R.; IZIDORO, D.R.; MASSON, M.L. Rheological characterization of blackberry pulp. Brazilian Journal Food Technology, v.9, n.4, p.291-296, 2006.

22 HERNANDEZ, E.; CHEN, C.S.; JONHSON, J.; CARTED, R.D. Viscosity changes in orange juice after ultra-filtration and evaporation. Journal of Food Engineering, v.25, n.3, p.387-396, 1995.

23 IAL. Instituto Adolfo Lutz. Normas analíticas do Instituto Adolfo Lutz. São Paulo, 1985.

24 IBARZ, A.; BARBOSA-CÁNOVAS, G.V. Operaciones unitarias en la ingeniería de alimentos. Guyton, GA: Taylor \& Francis, 1999.

25 KARNOVSKY, M.J.A. Formaldehyde-glutaraldehyde fixative of high osmolality for use in electron microscopy. Journal of Cell Biology, v.27, n.15, p.137-138, 1965.

26 LIMA, M.C. Bacuri (Platonia insignis Mart. Clusiaceae): agrobiodiversidade. São Luís: IICA, 2007.

27 MORAES, V.H.F.; MÜILLER, C.H.; SOUZA, A.G.C.; ANTÔNIO, I.C. Native fruit species of economic potential from the Brazilian Amazon. Angewandte Botanik, v.68, p.47-52, 1994.

28 NAGY, S.; CHEN, C.S.; SHAW, P.E. Fruit juice processing technology. Auburndale, Flórida: Agscience Inc., 1993.

29 NAZARÉ, R.F.R. de. Produtos agroindustriais de bacuri, cupuaçu, graviola e açaí, desenvolvidos pela Embrapa Amazônia Oriental. Belém: Embrapa Amazônia Oriental, 2000.

30 NIST. National Institute of Standards and Techonology. Base de dados de referência padrão do Nist. (2005). Avaliable at: URL: http://webbook.nist.gov/chemistry/. Access on: September 23, 2005.

31 RAO, M.A. Rheology of liquid foods - a review. Journal of Texture Studies, v.8, n.2, p.135-168, 1977.

32 SANTOS, M.S.S.A. Caracterização física e química do bacuri (Platonia insignis Mart.) e processamento de néctares. Boletim do CEPPA, v.6, p.73-78, 1988.

33 SABBE, S.; VERBEKE, W.; DAMME, P.V. Analysing the market environment for açaí (Euterpe oleracea Mart.) juices in Europe. Fruits, v.64, n.5, p.273-284, 2009.

34 SCHIEBER, A.; FÜGEL, R.; HENKE, M.; CARLE, R. Determination of the fruit content of strawberry fruit preparations by gravimetric quantification of hemicellulose. Food Chemistry, v.91, n.2, p.365-371, 2005.

35 SOUZA, V.A.B.; ARAÚJO, E.C.E.; VASCONCELOS, L.F.L.; LIMA, P.S.C. Variabilidade de características físicas e químicas de frutos de germoplasma de bacuri da Região Meio-Norte do Brasil. Revista Brasileira de Fruticultura, v.23, n. 3, p.677-683, 2001.

36 STATSOFT, Inc. Statistica for Windows: computer program manual. Tulsa, OK, USA, 2004.

37 STEFFE, J.F. Rheological methods in food process engineering. Michigan: Freeman Press, 1996.

38 STROHECKER, R.; HENNING, H.M. Analisis de vitaminas: métodos comprobados. Madrid: Paz Montalvo, 1967.

39 TANGLERTPAIBUL, T.; RAO, M.A. Rheological properties of tomato concentrates as affected by particle size and methods of concentration. Journal of Food Science, v.52, n.1, p.141-145, 1987.

40 TORRES, L.B.V.; QUEIROZ, A.J.M.; FIGUEIRÊDO, R.M.F. Viscosidades aparentes de polpas de umbu-cajá. Revista Brasileira de Produtos Agroindustriais, v.5, n.2, p.161-168, 2003.

41 VAN DEN BERG, M.E. Plantas medicinais na Amazônia: contribuição ao seu conhecimento sistemático (Medicine plants from the Amazon). Belém: Museu Emilio Goeldi, 1993.

42 VIDAL, B.C. Acid glycosaminoglycans and endochondral ossification: microspectrophotometric evaluation and macromolecular orientation. Cell Molecular Biology, v.22, n.1, p.45-64, 1977.

43 VIDAL, J.R.M.B. Comportamento reológico da polpa de manga (Mangífera indica L.). 2000. 159 p. Tese (Doutorado em Engenharia de Alimentos), Universidade de Campinas, Campinas, 2000.

44 VIDAL, J.R.M.B.; SIERAKOWSKI, M.R.; HAMINIUK, C.W.I.; MASSON, M.L. Propriedades reológicas da polpa de manga (Mangifera indica L. cv. Keitt) centrifugada. Ciência e Agrotecnologia, v.30, n.5, p.955-960, 2006.

45 VILLACHICA, H.; CARVALHO, J.E.U. de; MÜLLER, C.H.; DIAZ, S.C.; ALMANZA, M. Frutales y hortaliças promossoras de la Amazônia. Lima: Tratado de Cooperación Amazônica, 1996. 
46 VITALI, A.A.; RAO, M.A. Flow properties of low-pulp concentrated orange juice: effect of temperature and concentration. Journal of Food Science, v.49, n.3, p.882-888, 1984.

47 WILLER, H.; YUSSEFI-MENZLER, M.; SORENSEN, N. The world of organic agriculture: statistics and emerging trends. Bonn: IFOAM, 2008.

\section{ACKNOWLEDGMENTS}

We are indebted to CNPq (National Council of Technological and Scientific Development) for granting the graduate studies scholarship. 